\title{
ANALISIS PERILAKU BANGUNAN TOWER ATC MENGGUNAKAN SISTEM SHEAR WALL DAN TANPA SHEAR WALL (STUDI KASUS: TOWER ATC PADA BANDAR UDARA INTERNASIONAL SULTAN AJI MUHAMMAD SULAIMAN, SEPINGGAN, BALIKPAPAN)
}

\author{
(Analysis on Behaviour of Buildings Using Shear Wall and without Shear Wall \\ (Case Study: ATC Tower at International Airport Sultan Aji Muhammad Sulaiman, \\ Sepingan, Balikpapan)) \\ Gerry Rahadiansyah ${ }^{1}$, Niken Warastuti ${ }^{1}$, Fadli Kurnia ${ }^{1}$ \\ ${ }^{1}$ Program Studi Teknik Sipil, Fakultas Teknik, Universitas Pancasila \\ E-mail: gerryrahadiansyah@gmail.com
}

\begin{abstract}
ABSTRAK
Kebutuhan masyarakat akan transportasi udara menyebabkan kepadatan arus lalu lintas udara yang semakin dirasakan pada umumnya sebagai konsumen pemakai jasa/penumpang. Seringkali terjadi kecelakaan dalam penerbangan, pelanggaran suatu wilayah udara yang dilakukan oleh pesawat udara yang mengakibatkan penumpang tidak selamat. Maka dari itu dibuatlah menara pengawas lalu lintas udara atau Air Traffic Control (ATC). Pada studi kasus Tower ATC yang merupakan bangunan tower pemantau dengan 9 lantai, sistem struktur penahan lateral baja dan beton bertulang yang dapat dipilih untuk digunakan adalah sistem shear wall atau tanpa sistem shear wall. Analisis dilakukan guna mendapatkan perbedaan perilaku struktur dari kedua pemodelan tersebut serta memperoleh sistem struktur penahan lateral yang lebih baik untuk Tower ATC dilihat dari perilaku strukturnya. Berdasarkan hasil analisis yang telah dilakukan menunjukkan bahwa perilaku struktur dari kedua pemodelan berdasarkan nilai momen, gaya geser, waktu getar, simpangan antar lantai dan displacement samasama baik dan dapat diterima. Namun, untuk Tower ATC perilaku struktur lebih baik saat menggunakan shear wall atau pada pemodelan 1, dikarenakan momen, gaya geser dan displacement yang lebih kecil.
\end{abstract}

Kata Kunci: Bangunan Tinggi, Sistem Struktur Penahan Lateral, Shear Wall

\section{ABSTRACT}

Needs for air transportation cause traffic congestion in air generally perceived as consumers / passenger service users. Often there was an accident in flight, offense an airspace conducted by aircraft that makes passengers not safe. Therefore, it requires a watchtower air traffic or Air Traffic Control (ATC). On ATC Tower case which is a 9 stories building, the lateral retaining structural systems that can be used are shear wall system and without shear wall system. The analysis was performed to get structure behavior differences between two building models and better lateral retaining system for ATC Tower based on its structural behavior. The values of the analysis results shown that the two models are equally good and acceptable based on its torque, shear force, period of vibration, story drift and displacement. However, for ATC Tower case, the structural behavior is better when using shear wall or on 1st modeling because of its smaller moment, shear forces, and displacement.

Keyword: High-rise Building, Lateral Retaining Structural System, Shear Wall 


\section{PENDAHULUAN}

Kebutuhan masyarakat akan transportasi udara menyebabkan kepadatan arus lalu lintas udara yang semakin dirasakan pada umumnya sebagai konsumen pemakai jasa/penumpang. Seringkali terjadi kecelakaan dalam penerbangan, pelanggaran suatu wilayah udara yang dilakukan oleh pesawat udara yang mengakibatkan penumpang tidak selamat. Maka dari itu dibuatlah menara pengawas lalu lintas udara atau Air Traffic Control (ATC).

Pada struktur bangunan tinggi, beban yang dominan adalah beban-beban arah horizontal (beban lateral) yang merupakan beban gempa dan angin. Beban lateral tersebut dapat menghasilkan suatu deformasi struktur yang sangat besar dan menyebabkan ketidakstabilan struktur. Oleh karena itu, pada struktur bangunan tinggi dibutuhkan sistem struktur khusus sebagai perkuatan guna menahan beban lateral tersebut. Ada berbagai macam sistem struktur penahan lateral yang berdasarkan material yang digunakannya dibagi menjadi dua, yaitu struktur baja dan struktur beton bertulang. Salah satu cara pemilihan sistem struktur penahan lateral ditentukan berdasarkan jumlah lantai bangunan, karena semakin banyak lantai dan semakin tinggi bangunan maka diperlukan sistem yang lebih efektif.

Pada studi kasus Tower ATC yang merupakan bangunan tower pemantau dengan 9 lantai, sistem struktur penahan lateral baja dan beton bertulang yang dapat dipilih untuk digunakan adalah sistem shear wall atau tanpa sistem shear wall. Pilihan sistem struktur penahan lateral tersebut didapatkan berdasarkan tabel hubungan sistem penahan lateral dan jumlah lantai (Taranat, 2005) yang dapat dilihat di bawah ini.

Tabel 1. Hubungan Sistem Penahan Lateral dan Jumlah Lantai

\begin{tabular}{|c|c|c|c|c|c|c|c|c|c|c|c|c|c|}
\hline \multirow{2}{*}{ Lateral Steel Structural Sytem } & \multicolumn{13}{|c|}{ Number of Stories } \\
\hline & 10 & 20 & 30 & 40 & 50 & 60 & 70 & 80 & 90 & 100 & 110 & 120 & 130 \\
\hline \multicolumn{14}{|l|}{ Rigid frame } \\
\hline \multicolumn{14}{|l|}{ Braced frame } \\
\hline \multicolumn{14}{|l|}{ Staggered tussed system } \\
\hline \multicolumn{14}{|l|}{ Eccentric braced system } \\
\hline \multicolumn{14}{|l|}{ Braced system and rigid frame } \\
\hline \multicolumn{14}{|l|}{$\begin{array}{l}\text { Braced system and rigid frame } \\
\text { Outrigger and belt truss system }\end{array}$} \\
\hline \multicolumn{14}{|l|}{$\begin{array}{l}\text { Outrigger and belt truss system } \\
\text { Frame tube }\end{array}$} \\
\hline \multicolumn{14}{|l|}{ Trussed tube } \\
\hline \multicolumn{14}{|l|}{ Bundled tube } \\
\hline & & & & & & & & & & & & & \\
\hline floor framing & & & & & & & & & & & & & \\
\hline
\end{tabular}

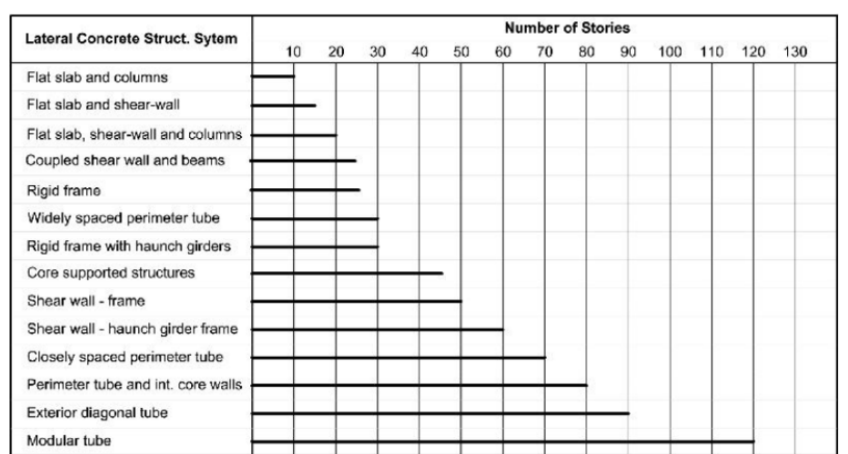

Sumber: Taranat S. Bungale, 2005

Sistem penahan lateral shear wall atau tanpa shear wall dapat digunakan salah satunya. Berdasarkan paparan di atas, penulis akan menganalisis perbandingan perilaku struktur Tower ATC ketika menggunakan sistem struktur penahan lateral shear wall dan tanpa shear wall dengan membuat pemodelan menggunakan software ETABS.

Tujuan dari dilakukannya analisis ini antara lain adalah:

1. Mendapatkan gambaran perilaku struktur bangunan tinggi (Tower ATC) berupa nilai momen, gaya geser, waktu getar, simpangan antar lantai dan displacement dengan sistem struktur menggunakan shear wall dan tanpa shear wall.

2. Memperoleh perbandingan perilaku struktur bangunan tinggi (Tower ATC) berdasarkan nilai momen, gaya geser, waktu getar, simpangan antar lantai dan displacement.

3. Mendapatkan sistem struktur penahan lateral yang lebih baik dan tepat untuk bangunan tinggi (Tower ATC) dilihat dari perilaku strukturnya.

\section{METODE}

Berikut merupakan flow chart atau diagram alur dari pemodelan hingga analisis pada Tugas Akhir ini. 


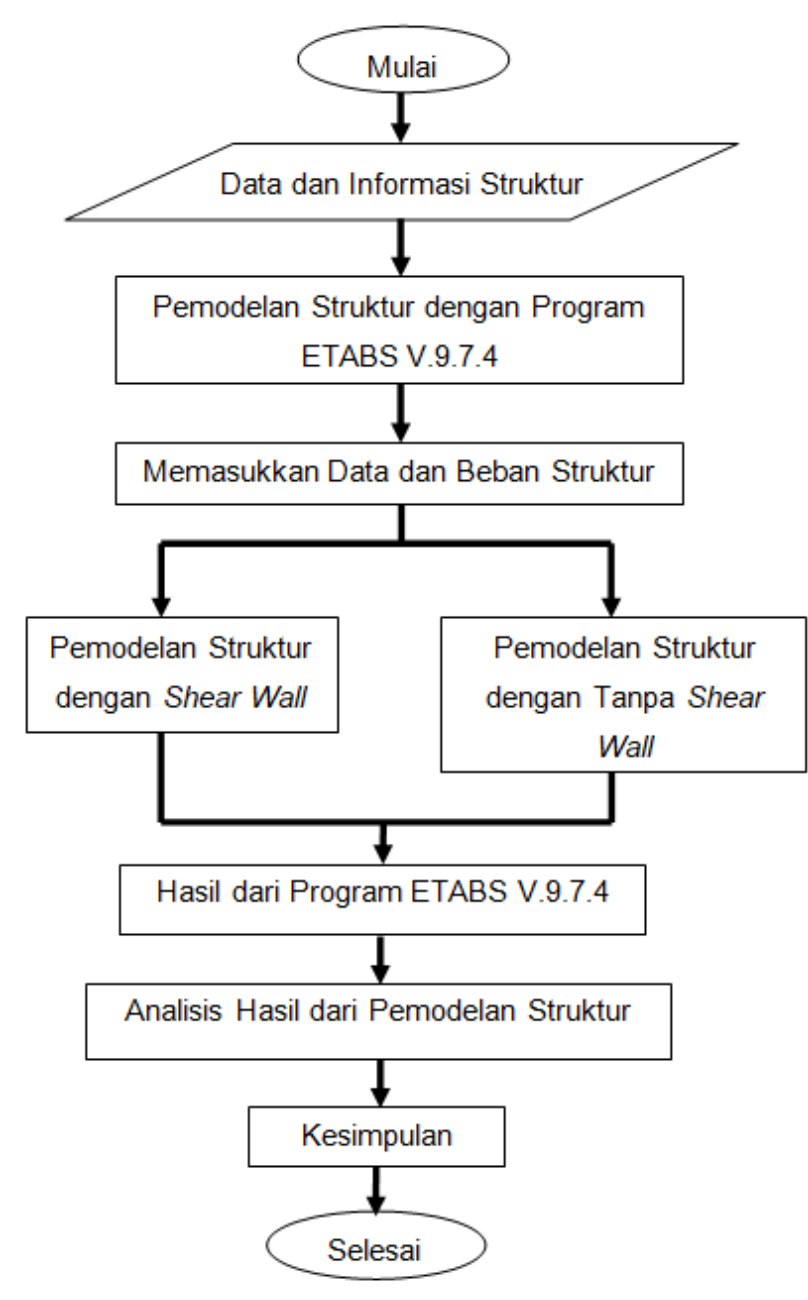

Gambar 1. Flow Chart Analisis Penelitian

Proses dimulai dengan pengumpulan data dan informasi struktur yang akan digunakan untuk pemodelan. Data-data yang digunakan adalah data teknis, antara lain:

- Lokasi Studi Kasus : Jalan Marsma R. Iswahyudi, Sepinggan, Balikpapan Sel., Kota Balikpapan, Kalimantan Timur.

- Luas Lahan $: 1.293,4 \mathrm{~m}^{2}$

- Luas Bangunan $: 1.824,4801 \mathrm{~m}^{2}$

- Tinggi Bangunan : $35 \mathrm{~m}$ dari elevasi jalan

- Ukuran dan Detail Kolom

- Ukuran dan Detail Balok

- Tipe dan Ukuran Pelat

- Ukuran dan Detail Shear Wall

- Mutu Beton dan Mutu Tulangan

- Denah Lantai

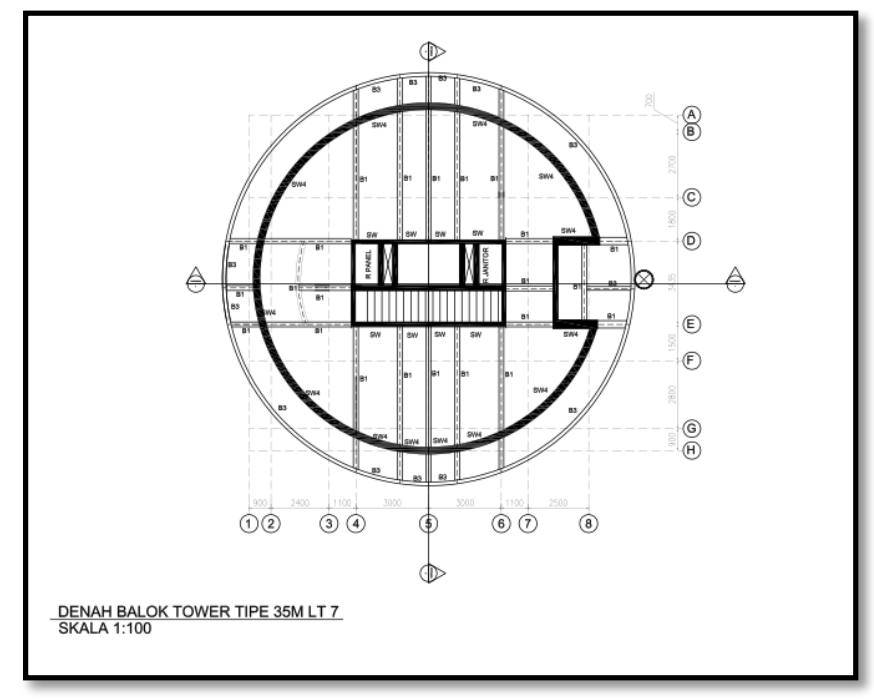

Gambar 2. Denah Lantai Tower ATC

Setelah didapatkan data dan informasi struktur seperti di atas, maka dapat dilakukan pemodelan dengan menggunakan software ETABS. Dari pemodelan tersebut maka didapatkan hasil yang akan dianalisis dan terakhir ditarik kesimpulan.

\section{HASIL DAN PEMBAHASAN}

\section{Variasi Pemodelan}

Ada dua variasi pemodelan sistem struktur penahan lateral pada Tower ATC yang kemudian akan dianalisis perilaku strukturnya menggunakan program bantu ETABS V9.7.4, yaitu:

1. Tower ATC dengan shear wall yang ditempatkan dari lantai dasar hingga lantai 9.

2. Tower ATC balok dan kolom sebagai pengganti shear wall yang sebelumnya ditempatkan dari lantai dasar hingga lantai atap.

\section{Perhitungan Pembebanan}

Pembebanan yang akan dimasukkan ke dalam pemodelan antara lain adalah sebagai berikut.

\section{Beban Mati}

Termasuk beban mati yaitu berat sendiri elemen struktur yang akan dihitung otomatis pada software ETABS 9.7.4 dengan berat jenis beton dan baja sebagai berikut:

$$
\begin{aligned}
& \text { Berat Jenis Beton }=2400 \mathrm{~kg} / \mathrm{m}^{2} \\
& \text { Berat Jenis Baja }=7850 \mathrm{~kg} / \mathrm{m}^{2}
\end{aligned}
$$

Ditambah dengan beban mati tambahan (super imposed dead load), yaitu sebagai berikut:

- Beban Mati Pada Balok:
Beban Façade
$: 0,40 \mathrm{kN} / \mathrm{m}^{2}$ 
- Beban Mati Pada Pelat Lantai:

Beban Instalasi ME

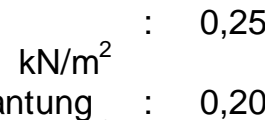

Beban Plafond dan Penggantung

Beban Rise Floor

$\mathrm{kN} / \mathrm{m}^{2}: 0,20$

Total Beban Mati Pada Pelat Lantai $\quad 0,65$ $\mathrm{kN} / \mathrm{m}^{2}$

- Beban Mati Pada Pelat Atap:

Beban Instalasi ME

$$
\mathrm{kN} / \mathrm{m}^{2}: 0,25
$$

Beban Plafond dan Penggantung ${ }_{2}: \quad 0,20$ $\mathrm{kN} / \mathrm{m}^{2}$

Beban Waterproofing $\stackrel{0}{:} 0,28$

Total Beban Mati Pada Pelat Atap $\mathrm{kN} / \mathrm{m}^{2}$

\section{Beban Hidup}

Beban Hidup yang digunakan pada Tower ATC ini memiliki besaran yang sama yaitu sebesar $2,40 \mathrm{kN} / \mathrm{m} 2$ dari lantai dasar hingga lantai atap.

\section{Beban Angin}

Acuan yang dipakai untuk menentukan beban angin adalah Peraturan Pembebanan Indonesia (PBI) 1983. Berdasarkan lokasi gedung Menara Astra yang jauh dari laut maka diambil tekanan tiup angin minimum, yaitu $25 \mathrm{~kg} / \mathrm{m}^{2}$.

\section{Beban Gempa}

Analisis beban gempa dilakukan dengan cara dinamik respon spektrum dan didasarkan pada SNI 1726-2012 sebagai berikut:

- Kategori Resiko :I

- Wilayah Gempa : 1 (Balikpapan)

- Jenis Tanah : Tanah Sedang

- Analisa Gempa : Respon Spektrum

- Ie $\quad: 1,0$

- Kelas Situs : SD

Berdasarkan lokasi Tower ATC, yaitu di Balikpapan maka Tower ATC termasuk kedalam wilayah gempa 1 dan berdasarkan data teknis dapat diketahui bahwa jenis tanah di lokasi tersebut merupakan tanah sedang. Data wilayah gempa dan jenis tanah tersebut selanjutnya dimasukkan kedalam website http://puskim.pu.go.id untuk mendapatkan output seperti pada Gambar 3 di bawah ini.

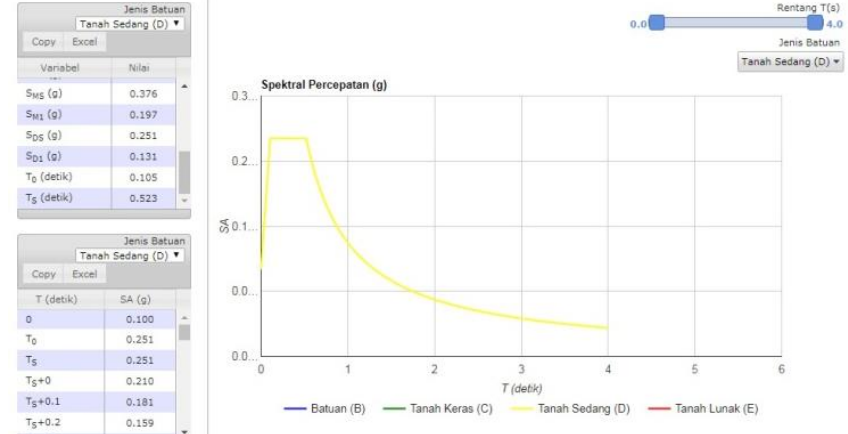

Gambar 3. Output Desain Spektrum

Seperti yang dapat dilihat pada Gambar 3 hasil yang didapatkan antara lain adalah grafik respon spektrum, hasil output percepatan gempa $\left(S_{s}, S_{1}\right)$ untuk lokasi gedung Menara Astra, yaitu sebesar $S_{s}=0.235$ dan $S_{1}=0.082$. Didapat juga nilai parameter $S_{M S}=0.376$ dan $\mathrm{S}_{\mathrm{M} 1}=0.197$.

Penentuan Kategori Desain Seismik (KDS) didasarkan pada kategori resiko $=\| \mathrm{I}$ serta $\mathrm{S}_{\mathrm{DS}}=$ 0.251 dan $S_{D 1}=0.131$ sebagai berikut.

Tabel 2. Kategori Desain Seismik Berdasarkan

\begin{tabular}{|c|c|c|}
\hline \multicolumn{2}{|c|}{$S_{\mathrm{DS}}$} \\
\hline \multirow{2}{*}{ Nilai $S_{D S}$} & \multicolumn{2}{|c|}{ Kategori risiko } \\
\hline$S_{D S}<0,167$ & I atau II atau III & IV \\
\hline $0,167 \leq S_{D S}<0,33$ & $\mathrm{~A}$ & $\mathrm{~A}$ \\
\hline $0,33 \leq S_{D S}<0,50$ & $\mathrm{~B}$ & $\mathrm{C}$ \\
\hline $0,50 \leq S_{D S}$ & $\mathrm{C}$ & $\mathrm{D}$ \\
\hline
\end{tabular}

Sumber: SNI 1726-2012

Tabel 3. Kategori Desain Seismik Berdasarkan $\mathrm{S}_{\mathrm{D} 1}$

\begin{tabular}{|c|c|c|}
\hline \multirow{2}{*}{ Nilai $S_{D 1}$} & \multicolumn{2}{|c|}{ Kategori risiko } \\
\cline { 2 - 3 } & I atau II atau III & IV \\
\hline$S_{D 1}<0,167$ & $\mathrm{~A}$ & $\mathrm{~A}$ \\
\hline $0,067 \leq S_{D 1}<0,133$ & $\mathrm{~B}$ & $\mathrm{C}$ \\
\hline $0,133 \leq S_{D 1}<0,20$ & $\mathrm{C}$ & $\mathrm{D}$ \\
\hline $0,20 \leq S_{D 1}$ & $\mathrm{D}$ & $\mathrm{D}$ \\
\hline
\end{tabular}

Sumber: SNI 1726-2012

Berdasarkan tabel di atas, $0.167<\mathrm{S}_{\mathrm{DS}}<0.33$ dan $0.067<\mathrm{S}_{\mathrm{D} 1}<0.133$ didapatkan Kategori Desain Seismik (KDS) termasuk kategori resiko B.

Berdasarkan SNI 1726-2012 dirumuskan pemilihan sistem struktur seperti pada Tabel 4 berikut. 
Tabel 4. Pemilihan Sistem Struktur Berdasarkan Tingkat Resiko Gempa

\begin{tabular}{|c|c|c|c|}
\hline \multirow{2}{*}{ Code } & \multicolumn{3}{|c}{ Tingkat Resiko Kegempaan } \\
\cline { 2 - 4 } SNI 03-1726-2012 & Rendah & Menengah & Tin \\
\cline { 2 - 4 } & A, B & C & D, E \\
\hline Sistem Penahan & SRMB/ M/K & SRMM/K & SRI \\
Gempa & $\mathrm{SDSB} / \mathrm{K}$ & $\mathrm{SDSB} / \mathrm{K}$ & $\mathrm{SD}$ \\
\hline
\end{tabular}

Sumber: SNI 1726-2012

Dari Tabel 4 dapat dilihat bahwa struktur Tower ATC termasuk ke dalam kategori resiko gempa rendah (B), sehingga digunakan sistem penahan gempa SRMB (Struktur Rangka Momen Biasa). Berdasarkan SNI 1726-2012 untuk rangka beton bertulang pemikul momen khusus didapatkan nilai faktor $\mathrm{R}, \mathrm{Cd}$ dan $\Omega_{0}$ seperti pada Tabel 5 berikut.

Tabel 5. Faktor R, Cd, $\Omega_{0}$ untuk Sistem

\begin{tabular}{|c|c|c|c|c|c|c|}
\hline \multirow[t]{2}{*}{ Sistem penahan-gaya gempa } & \multirow{2}{*}{$\begin{array}{c}\begin{array}{c}\text { Koefisien } \\
\text { modifikasi } \\
\text { respons, }\end{array} \\
R^{a}\end{array}$} & \multirow{2}{*}{$\begin{array}{c}\begin{array}{c}\text { Faktor } \\
\text { kuat.lebih } \\
\text { sistem, }\end{array} \\
\Omega_{0}{ }^{g}\end{array}$} & \multirow{2}{*}{$\begin{array}{c}\text { Faktor } \\
\text { pembesaran } \\
\text { defleksi, } \\
C_{d}^{b}\end{array}$} & \multicolumn{3}{|c|}{$\begin{array}{r}\begin{array}{r}\text { Batasan sistem } \\
\text { batasan tinggi }\end{array} \\
\text { Kategori desi }\end{array}$} \\
\hline & & & & $\mathrm{B}$ & $\mathrm{C}$ & $\overline{\mathrm{D}^{d}}$ \\
\hline $\begin{array}{l}\text { 5. Rangka beton bertulang pemikul momen } \\
\text { khusus }\end{array}$ & 8 & 3 & $5 \frac{1 / 2}{2}$ & TB & $T B$ & TB \\
\hline $\begin{array}{l}\text { 6. Rangka beton bertulang pemikul momen } \\
\text { menengah }\end{array}$ & 5 & 3 & $4 \frac{11 / 2}{2}$ & TB & TE & $\mathrm{TI}$ \\
\hline 7. Rangka beton bertulang pemikul momen biasa & 3 & 3 & $2^{1 / 2}$ & TB & $\mathrm{TI}$ & $\mathrm{TI}$ \\
\hline $\begin{array}{l}\text { 8. Rangka baja dan beton komposit pemikul } \\
\text { momen khusus }\end{array}$ & 8 & 3 & $5 \frac{1}{2}$ & TB & TE & TB \\
\hline $\begin{array}{l}\text { 9. Rangka baja dan beton komposit pemikul } \\
\text { momen menengah }\end{array}$ & 5 & 3 & $4 \frac{1}{2}$ & TB & $T B$ & TI \\
\hline
\end{tabular}

Sumber: SNI 1726-2012

Dari tabel di atas didapatkan nilai faktor $\mathrm{R}=3$, $\mathrm{Cd}=2,5$ dan $\Omega_{0}=3$.

\section{Kombinasi Beban (Load Combination)}

Kombinasi pembebanan yang akan dilakukan pada analisis kali ini adalah sebagai berikut:

- 1,4 D + 1,4 SW

- 1,2 D + 1,2 SW + 1,6 L

- 1,2 D + 1,2 SW + 0,5 L + 1 RSPx

- 1,2 D + 1,2 SW + 0,5 L - 1 RSPx

- 1,2 D + 1,2 SW + 0,5 L + 1 RSPy

- 1,2 D + 1,2 SW + 0,5 L - 1 RSPy

Keterangan:

D = Beban Mati Tambahan (Super Imposed Dead Load)

SW = Beban Mati Sendiri (Self Weight)

$\mathrm{L} \quad=$ Beban Hidup (Live)

RSPx = Respon Spektrum Arah X

RSPy $=$ Respon Spektrum Arah $Y$

\section{Hasil Pemodelan}

Berikut merupakan hasil dari 2 pemodelan gedung Menara Astra pada program ETABS V9.6.0.

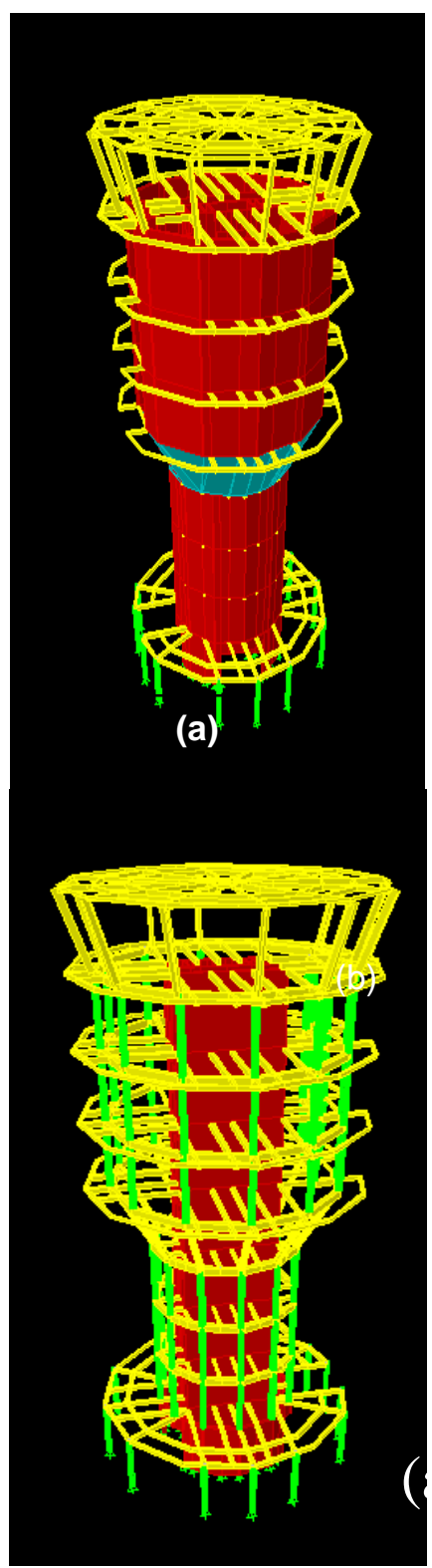

Gambar 4. Hasil Pemodelan Struktur dengan ETABS; (a) Struktur dengan Shear Wall; (b) Struktur dengan balok dan kolom pengganti Shear Wall

\section{Evaluasi Hasil Analisis Perilaku Struktur}

Dalam mencapai tujuan untuk mengetahui perbedaan dan perubahan perilaku struktur bangunan ketika menggunakan sistem struktur penahan lateral shear wall dan kombinasi balok dan kolom dilihat dari faktor-faktor perilaku seperti momen, gaya geser, waktu getar, simpangan antar lantai dan displacement. Maka dilakukan evaluasi hasil analisis pemodelan yang dilakukan dengan software ETABS V9.7.4. 


\section{Analisis Momen}

Momen yang terjadi pada kedua pemodelan struktur dapat dilihat pada Gambar 5 di bawah ini.

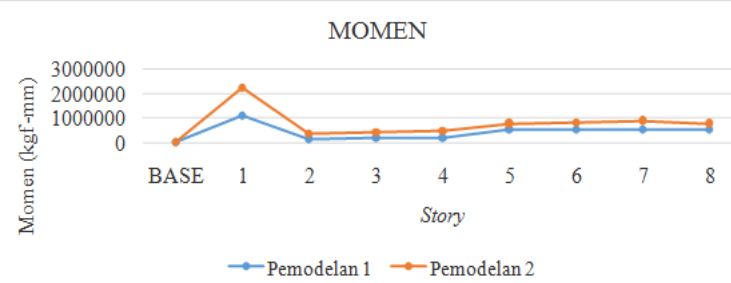

Gambar 5. Grafik Momen

Dari data rekapitulasi momen yang terjadi, pada pemodelan 1 dengan menggunakan sistem struktur penahan lateral shear wall memiliki nilai momen lebih kecil dibandingkan dengan pemodelan 2 yang menggunakan balok sebagai pengganti shear wall seperti yang dapat dilihat pada grafik di atas. Hal ini disebabkan oleh berat struktur pemodelan 2 yang lebih besar dibandingkan berat struktur pemodelan 1. Berat struktur merupakan salah satu faktor yang mempengaruhi nilai momen, semakin berat struktur maka akan semakin besar pula nilai momen dari struktur tersebut. Berikut merupakan tabel nilai momen maksimum yang terjadi pada pemodelan 1 dan pemodelan 2 .

Tabel 6. Momen Maksimum

\begin{tabular}{c|c|c}
\hline Pemodelan & Momen (Kgf.m) & Momen (ton.m) \\
\hline 1 & $1.079 .646,90$ & $1.079,65$ \\
\hline 2 & $2.260 .800,76$ & $2.260,80$ \\
\hline
\end{tabular}

Dari Tabel 6 di atas dapat dilihat bahwa nilai momen maksimum dari pemodelan 2 dengan menggunakan balok sebagai pengganti shear wall lebih besar yaitu $2.260,80$ ton.m, sedangkan nilai momen pemodelan 1 yang menggunakan shear wall adalah 1.079,65 ton.m.

\section{Analisis Gaya Geser}

Gaya geser dari kedua pemodelan dapat dilihat pada Gambar 6 di bawah.

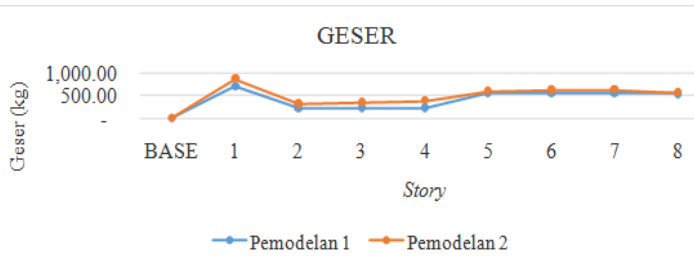

Gambar 6. Grafik Gaya Geser

Dari data rekapitulasi nilai gaya geser yang terjadi, gaya geser pada Tower ATC dengan menggunakan shear wall (pemodelan 1) memiliki gaya geser yang lebih kecil dibandingkan dengan Tower ATC dengan balok sebagai pengganti shear wall (pemodelan 2) seperti yang dapat dilihat pada grafik di atas. Berikut merupakan nilai gaya geser maksimum yang terjadi.

Tabel 7. Gaya Geser Maksimum

\begin{tabular}{c|c|c}
\hline Pemodelan & Gaya Geser (Kg) & Gaya Geser (ton) \\
\hline 1 & 702,70 & 0,702 \\
\hline 2 & 879,66 & 0,880 \\
\hline
\end{tabular}

Berdasarkan Tabel 7 dari hasil pemodelan dapat disimpulkan bahwa gaya geser berbanding lurus dengan berat struktur sama seperti momen. Hal tersebut dapat dibuktikan dari rumus gaya geser yang merupakan turunan dari momen, dimana besarnya nilai gaya geser dipengaruhi oleh seluruh beban-beban yang bekerja pada struktur. Oleh karena itu, gaya geser yang terjadi pada pemodelan 2 lebih besar dibandingkan dengan pemodelan 1, yaitu 0,880 ton. Sedangkan gaya geser yang terjadi pada pemodelan 1 lebih kecil, yaitu 0,702 ton.

\section{Analisis Waktu Getar}

Perilaku struktur yang baik adalah ketika terjadi translasi terlebih dahulu kemudian barulah terjadi rotasi. Dari hasil pemodelan dengan ETABS pola mode shape dari pemodelan 1 dengan menggunakan core wall dan pemodelan 2 dengan menggunakan kombinasi core wall belt truss memiliki pola yang sama, yaitu:

- Mode shape 1: Translasi

- Mode shape 2: Translasi

- Mode shape 3: Rotasi

Tabel 8. Mode Shape dan Waktu Getar

\begin{tabular}{c|c|c|c|c|c|c|c|c}
\hline Pemodelan & Mode & Period (s) & RX & RY & RZ & SumRX & SumRY & SumRZ \\
\hline \multirow{4}{*}{1} & 1 & 0.822505 & 6.9122 & 0.4224 & 8.1903 & 6.9122 & 0.4224 & 8.1903 \\
\cline { 2 - 9 } & 2 & 0.784287 & 19.6378 & 32.6827 & 0.5525 & 26.55 & 33.1051 & 8.7427 \\
\cline { 2 - 9 } & 3 & 0.767281 & 46.1096 & 19.7404 & 0.4835 & 72.6596 & 52.8455 & 9.2262 \\
\hline \multirow{3}{*}{2} & 1 & 1.524772 & 86.7137 & 0.2902 & 1.6954 & 86.7137 & 0.2902 & 1.6954 \\
\cline { 2 - 9 } & 2 & 1.283172 & 2.0527 & 8.2274 & 62.9764 & 88.7664 & 8.5176 & 64.6718 \\
\cline { 2 - 9 } & 3 & 1.014464 & 0.0013 & 57.0323 & 5.8719 & 88.7678 & 65.5499 & 70.5437 \\
\hline
\end{tabular}


Dari Tabel 8 diatas dapat dilihat bahwa waktu getar yang lebih kecil dimiliki oleh pemodelan 2 Tower ATC dengan balok sebagai pengganti shear wall. Hal yang berperan penting dalam menentukan besar waktu getar suatu struktur adalah berat struktur dan kekakuannya. Berat dan kekauan struktur berbanding terbalik dengan waktu getar, semakin besar berat dan kekakuan struktur maka akan semakin kecil waktu getarnya. Oleh karena penggunaan shear wall pada pemodelan 1, maka didapat berat dan kekakuan struktur yang lebih besar sehingga dihasilkan waktu getar yang lebih kecil, yaitu 0,822505 detik. Sedangkan waktu getar pada pemodelan 2, yaitu 1,524772 detik. Tetapi, jika kita melihat dari pola mode shape pemodelan 1 maupun pemodelan 2 tidak sesuai dengan SNI.

\section{Analisis Simpangan Antar Lantai}

Simpangan antar lantai yang terjadi dapat dilihat pada Gambar 7 dan 8 di bawah ini. Gaya gempa yang diberikan saat pemodelan pada arah $\mathrm{X}$ adalah $100 \%$ dan pada arah $\mathrm{Y}$ adalah $30 \%$. Ketinggian antar lantai serta bentuk struktur setiap lantai pada Tower ATC berbedabeda, hal ini merupakan salah satu penyebab terjadinya kenaikan dan penurunan pada simpangan antar lantai yang dapat dilihat pada grafik di bawah. Dimana perbedaan tinggi dan bentuk setiap lantai tersebut akan mempengaruhi kekakuan struktur di setiap lantainya.

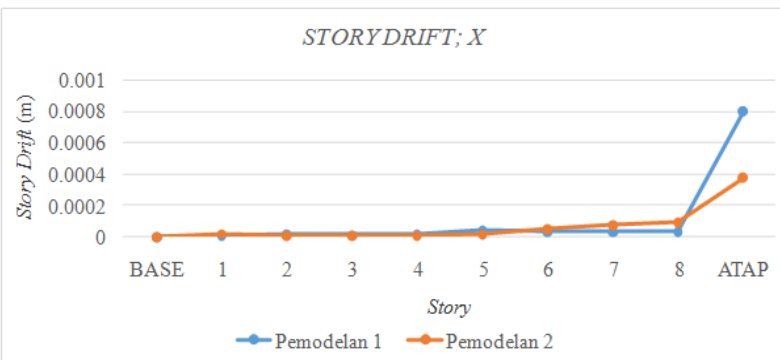

Gambar 7. Grafik Simpangan Antar Lantai Arah $\mathrm{X}$

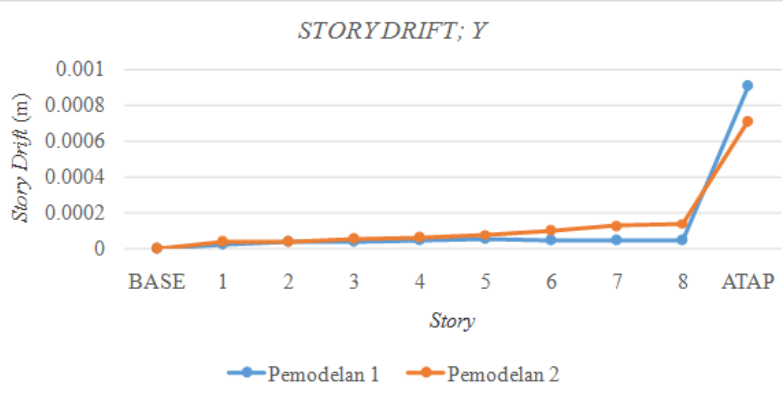

Gambar 8. Grafik Simpangan Antar Lantai Arah $Y$

Dari kedua grafik di atas dapat disimpulkan bahwa simpangan antar lantai dipengaruhi oleh kekakuan struktur. Penambahan penggunaan balok dan kolom pada pemodelan 2 membuat kekakuan struktur yang lebih besar dibandingkan dengan pemodelan 1, sehingga dapat mengekang dan mengurangi simpangan yang terjadi. Berikut merupakan tabel simpangan antar lantai maksimum yang terjadi pada kedua pemodelan Tower ATC.

Tabel 9. Simpangan Antar Lantai Maksimum

\begin{tabular}{c|c|c}
\hline \multirow{2}{*}{ Pemodelan } & \multicolumn{3}{|c}{ Simpangan Antar Lantai } \\
\cline { 2 - 3 } & $\mathbf{X}(\mathbf{m})$ & $\mathbf{Y}(\mathbf{m})$ \\
\hline 1 & 0,0008 & 0,000907 \\
\hline 2 & 0,000377 & 0,000709 \\
\hline
\end{tabular}

Simpangan antar lantai maksimum yang terjadi lebih kecil pada pemodelan 2, yaitu dengan simpangan 0,000377 $\mathrm{m}$ pada arah $\mathrm{x}$ dan $0,000709 \mathrm{~m}$ pada arah y. Sedangkan simpangan yang terjadi pada pemodelan 1, yaitu $0,0008 \mathrm{~m}$ pada arah $\mathrm{x}$ dan $0,000907 \mathrm{~m}$ pada arah y.

\section{Analisis Displacement}

Data rekapitulasi displacement pada pemodelan 1 dan pemodelan 2 Tower ATC dapat dilihat pada Gambar 9, 10 dan 11 berikut.

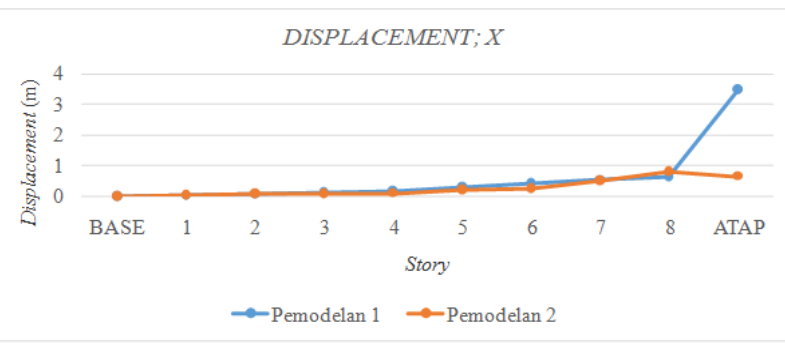

Gambar 9. Grafik Displacement Arah X

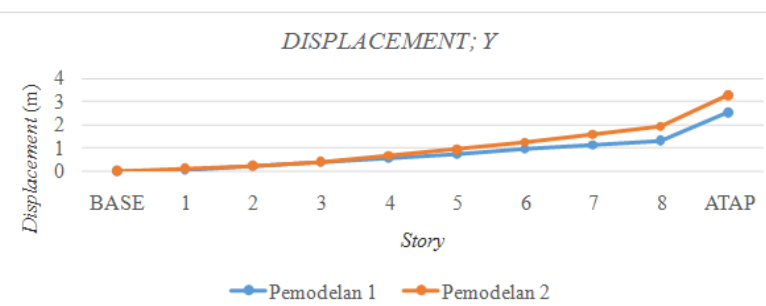

Gambar 10. Grafik Displacement Arah Y

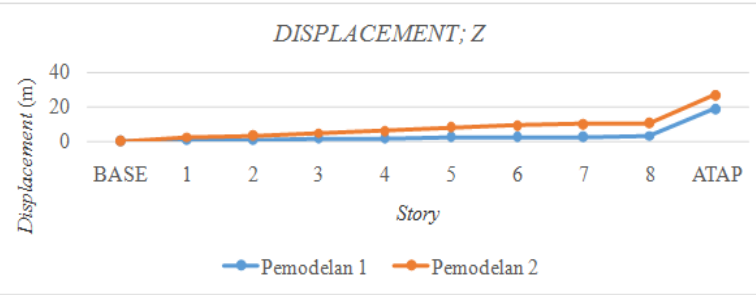

Gambar 11. Grafik Displacement Arah Z

Berdasarkan grafik di atas dapat disimpulkan

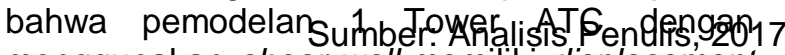
menggunakan shear wall memiliki displacement lebih kecil dibandingkan dengan pemodelan 2 
Tower ATC dengan menggunakan balok dan kolom sebagai pengganti shear wall. Berikut merupakan tabel nilai displacement maksimum dari masing-masing pemodelan.

Tabel 10. Displacement Maksimum

\begin{tabular}{c|c|c|c}
\hline \multirow{2}{*}{ Pemodelan } & \multicolumn{3}{|c}{ Displacement } \\
\cline { 2 - 4 } & $\mathbf{X}(\mathbf{m})$ & $\mathbf{Y}(\mathbf{m})$ & $\mathbf{Z}(\mathbf{m})$ \\
\hline 1 & 3,481 & 2,529 & 18,777 \\
\hline 2 & 0,650 & 3,264 & 26,704 \\
\hline
\end{tabular}

Dari Tabel 10 di atas dapat dilihat displacement maksimum yang terjadi pada pemodelan 2 lebih kecil dibandingkan pemodelan 1 dengan displacement 0,650 $\mathrm{m}$ arah $\mathrm{x}, 3,264 \mathrm{~m}$ arah $\mathrm{y}$ dan 26,704 $\mathrm{m}$ arah $\mathrm{z}$. Sedangkan displacement pada pemodelan 1 , yaitu $3,481 \mathrm{~m}$ arah $\mathrm{x}, 2,529$ $\mathrm{m}$ arah y dan $26,704 \mathrm{~m}$ arah $\mathrm{z}$.

\section{Perbandingan Hasil Analisis}

Berikut merupakan tabel perbandingan dari rekapitulasi hasil analisis pemodelan Tower ATC saat menggunakan shear wall dan saat menggunakan balok dan kolom sebagai pengganti shear wall.

Tabel 11. Perbandingan Hasil Analisis

\begin{tabular}{|c|c|c|c|c|c|c|}
\hline \multirow{2}{*}{ Keterangan } & \multicolumn{3}{|c|}{ Pemodelan 1} & \multicolumn{3}{|c|}{ Pemodelan 2} \\
\hline & $X(m)$ & $Y(m)$ & $Z(m)$ & $X(m)$ & $Y(m)$ & $Z(m)$ \\
\hline Momen (ton.m) & \multicolumn{3}{|c|}{$1.079,65$} & \multicolumn{3}{|c|}{$2.260,80$} \\
\hline Gaya Geser (ton) & \multicolumn{3}{|c|}{0,702} & \multicolumn{3}{|c|}{0,880} \\
\hline Waktu Getar (s) & \multicolumn{3}{|c|}{0,822505} & \multicolumn{3}{|c|}{1,524772} \\
\hline Simpangan Antar Lantai (m) & 0,0008 & 0,000907 & & 0,000377 & 0,000709 & \\
\hline Displacement (m) & 3,481 & 2,259 & 18,777 & 0,650 & 3,264 & 26,704 \\
\hline $\begin{array}{l}\text { `keterangan: } \\
\text { - Pemodelan 1: Tower ATC } \\
\text { - Pemodelan 2: Tower ATC } \\
\text { Tanpa Shea }\end{array}$ & $\begin{array}{l}\text { Vengan } \\
\text { Vall }\end{array}$ & & \multicolumn{4}{|c|}{$\begin{array}{l}\text { displacement yang lebih kecil dibandingkan } \\
\text { dengan saat menggunakan balok dan kolom } \\
\text { sebagai pengganti shear wall pada pemodelan } \\
2 \text {. }\end{array}$} \\
\hline
\end{tabular}

Dari tabel perbandingan hasil analisis perilaku struktur pemodelan Tower ATC berdasarkan momen, gaya geser, waktu getar, simpangan antar lantai dan displacement dapat dikatakan kedua pemodelan mempunyai perilaku struktur yang baik dan dapat diterima. Namun, untuk studi kasus Tower ATC perilaku struktur lebih baik saat menggunakan shear wall (pemodelan 1), karena memiliki momen, gaya geser dan

Tabel 12. Perbandingan Hasil Analisis

\section{KESIMPULAN}

Berdasarkan hasil analisis perilaku struktur pada gedung Menara Astra dengan menggunakan software ETABS V9.7.4, maka dapat ditarik kesimpulan sebagaimana terlampir pada Tabel 12 berikut.

\begin{tabular}{c|c|c|c|c|c|c}
\hline \multirow{2}{*}{ Keterangan } & \multicolumn{3}{|c|}{ Pemodelan 1 } & \multicolumn{3}{c}{ Pemodelan 2 } \\
\cline { 2 - 6 } & $\mathbf{X}(\mathbf{m})$ & $\mathbf{Y}(\mathbf{m})$ & $\mathbf{Z}(\mathbf{m})$ & $\mathbf{X}(\mathbf{m})$ & $\mathbf{Y}(\mathbf{m})$ & $\mathbf{Z}(\mathbf{m})$ \\
\hline Momen (ton.m) & \multicolumn{3}{|c|}{$1.079,65$} & \multicolumn{3}{c}{$2.260,80$} \\
\hline Gaya Geser (ton) & \multicolumn{3}{|c|}{0,702} & \multicolumn{3}{c}{1,580} \\
\hline Waktu Getar (s) & \multicolumn{3}{|c|}{0,822505} & 0,000377 & 0,000709 & \\
\hline Simpangan Antar Lantai (m) & 0,0008 & 0,000907 & & 0,650 & 3,264 & 26,704 \\
\hline Displacement (m) & 3,481 & 2,259 & 18,777 & &
\end{tabular}

Sumber: Analisis Penulis, 2018

*keterangan:

- Pemodelan 1: Tower ATC dengan Shear Wall

- Pemodelan 2: Tower ATC dengan dengan Tanpa Shear Wall 
1. Momen pada Pemodelan 1 lebih kecil dibandingkan Pemodelan 2, sehingga berdasarkan nilai momennya pemodelan 1 lebih baik.

2. Gaya geser pada Pemodelan 1 lebih kecil dibandingkan Pemodelan 2, sehingga berdasarkan gaya gesernya pemodelan 1 lebih baik.

3. Waktu getar pada Pemodelan 1 lebih kecil dibandingkan Pemodelan 2. Namun, kedua pemodelan tidak mempunyai pola mode shape yang sama yaitu translasi terlebih dahulu kemudian rotasi, sehingga berdasarkan perilaku strukturnya kedua perilaku struktur pemodelan kurang baik dan tidak dapat diterima.

4. Simpangan antar lantai pada Pemodelan 2 lebih kecil dibandingkan Pemodelan 1, sehingga berdasarkan simpangannya pemodelan 2 lebih baik.

5. Displacement pada Pemodelan 1 lebih kecil dibandingkan Pemodelan 2, sehingga berdasarkan displacementnya pemodelan 1 lebih baik.

6. Sistem struktur penahan lateral yang lebih baik dan tepat untuk Tower ATC dilihat dari perilaku strukturnya adalah Shear Wall, yaitu pada Pemodelan 1.

\section{REFERENSI}

Anonim. (2010). Sistem Struktur Bangunan Gedung. Diakses dari http://repository.binus.ac.id. [23 April 2017]

Ardi. (2002). Perencanaan Struktur Bangunan Tinggi. Diakses dari ardi.staff.gunadarma.ac.id/.../files/.../PERENCAN $A A N+S T R U k+$ bangunan+tingggi3. $\quad[25$ April 2017]

Dewobroto, W. (2012). Menyongsong Era Bangunan Tinggi dan Bentang Panjang. Universitas Pelita Harapan, Jakarta.

Gani, M. (2008). Evaluasi Kinerja Sistem Struktur Penahan Beban Lateral Dinding Geser Beton Bertulang dengan Outrigger. Tesis, Universitas Indonesia. Jakarta.

Orchidentus, R., D., J., \& S., R. (2016). Analisa Statik dan Dinamik Gedung Bertingkat Banyak Akibat Gempa Berdasarkan SNI 1726-2012 dengan Variasi Jumlah Tingkat. Universitas Sam Ratulangi, Manado.

Primasari, D. (2006). Karakteristik Dinamik Pada Penggunaan Outrigger Sebagai Solusi Penambahan Lantai Pada Struktur Bangunan Tingkat Tinggi (High Rise Building). Skripsi, Universitas Indonesia. Jakarta.

Sofia, F. (2008). Analisis Sistem Outrigger Pada Struktur Bangunan Tinggi. Skripsi, Universitas Indonesia. Jakarta.

Ubaidillah. (2006). Desain Struktur Portal - Dinding Geser dengan Variasi Daktilitas. Skripsi, Universitas Indonesia. Jakarta.

lezal. (2012). Studi Perbandingan Beban-Lendutan Dinding Slender Shear Wall yang Dianalisis Dengan Memasukan Faktor Modifikasi dan Dianalisis Secara Non-Linear. Jakarta: Universitas Indonesia. 
Halaman ini sengaja dikosongkan 